\title{
Upper Thermal Tolerances of Early Life Stages of Freshwater Mussels
}

Tamara J. Pandolfo

W. Gregory Cope

Consuelo Arellano

Robert B. Bringolf

M. Christopher Barnhart

Missouri State University

Follow this and additional works at: https://bearworks. missouristate.edu/articles-cnas

Part of the Biology Commons

\section{Recommended Citation}

Pandolfo, Tamara J., W. Gregory Cope, Consuelo Arellano, Robert B. Bringolf, M. Christopher Barnhart, and Edward Hammer. "Upper thermal tolerances of early life stages of freshwater mussels." Journal of the North American Benthological Society 29, no. 3 (2010): 959-969.

This article or document was made available through BearWorks, the institutional repository of Missouri State University. The work contained in it may be protected by copyright and require permission of the copyright holder for reuse or redistribution.

For more information, please contact BearWorks@library.missouristate.edu. 


\title{
Upper thermal tolerances of early life stages of freshwater mussels
}

\author{
Tamara J. Pandolfo, ${ }^{1,6}$, W. Gregory Cope ${ }^{1,7}$, Consuelo Arellano ${ }^{2,8}$, Robert \\ B. Bringolf ${ }^{3,9}$, M. Christopher Barnhart ${ }^{4,10}$, AND Edward Hammer ${ }^{5,11}$ \\ ${ }^{1}$ Department of Environmental and Molecular Toxicology, North Carolina State University, \\ Campus Box 7633, Raleigh, North Carolina 27695 USA \\ ${ }^{2}$ Department of Statistics, North Carolina State University, Raleigh, North Carolina 27695 USA \\ ${ }^{3}$ Warnell School of Forestry and Natural Resources, University of Georgia, Athens, Georgia 30602 USA \\ ${ }^{4}$ Department of Biology, Missouri State University, Springfield, Missouri 65897 USA \\ ${ }^{5}$ US Environmental Protection Agency, Chicago, Illinois 60604 USA
}

\begin{abstract}
Freshwater mussels (order Unioniformes) fulfill an essential role in benthic aquatic communities, but also are among the most sensitive and rapidly declining faunal groups in North America. Rising water temperatures, caused by global climate change, industrial discharges, drought, or land development, could further challenge imperiled unionid communities. The aim of our study was to determine the upper thermal tolerances of the larval (glochidia) and juvenile life stages of freshwater mussels. Glochidia of 8 species of mussels were tested: Lampsilis siliquoidea, Potamilus alatus, Ligumia recta, Ellipsaria lineolata, Lasmigona complanata, Megalonaias nervosa, Alasmidonta varicosa, and Villosa delumbis. Seven of these species also were tested as juveniles. Survival trends were monitored while mussels held at 3 acclimation temperatures $\left(17,22\right.$, and $\left.27^{\circ} \mathrm{C}\right)$ were exposed to a range of common and extreme water temperatures $\left(20-42^{\circ} \mathrm{C}\right)$ in standard acute laboratory tests. The average median lethal temperature (LT50) among species in $24-\mathrm{h}$ tests with glochidia was $31.6^{\circ} \mathrm{C}$ and ranged from 21.4 to $42.7^{\circ} \mathrm{C}$. The mean LT50 in 96-h juvenile tests was $34.7^{\circ} \mathrm{C}$ and ranged from 32.5 to $38.8^{\circ} \mathrm{C}$. Based on comparisons of LT50s, thermal tolerances differed among species for glochidia, but not for juveniles. Acclimation temperature did not affect thermal tolerance for either life stage. Our results indicate that freshwater mussels already might be living close to their upper thermal tolerances in some systems and, thus, might be at risk from rising environmental temperatures.
\end{abstract}

Key words: freshwater mussel, Unionidae, glochidia, juvenile, temperature, thermal tolerance, LT50, LT05.

Thermal regimes of freshwater environments can be altered by a variety of anthropogenic impacts, including climate change, landuse change, and thermal effluents from industry (Kinouchi et al. 2007, Encina et al. 2008). The effects of altered thermal regimes on fish have been elucidated (e.g., Eaton and Scheller 1996, Beitinger et al. 2000, Daufresne et al. 2003, Mohseni et al. 2003), but the effects of temperature on bivalves are less studied. The effects of temperature on the development, release, and viability of the larval life stage (glochidia) of fresh-

\footnotetext{
${ }^{6}$ E-mail addresses: tjpandol@ncsu.edu

7 greg_cope@ncsu.edu

8 arellano@stat.ncsu.edu

9 rbringolf@warnell.uga.edu

10 chrisbarnhart@missouristate.edu

11 hammer.edward@epa.gov
}

water mussels of the bivalve order Unioniformes have been investigated (Roberts and Barnhart 1999, Jansen et al. 2001, Zimmerman and Neves 2002, Akiyama and Iwakuma 2007, Cope et al. 2008), but a data gap exists in the determination of acute lethal temperatures for the early life stages (Dimock and Wright 1993). Determination of the upper thermal limits of mussels is vital because changes in extreme temperatures, resulting from higher summer maximum temperatures induced by global climate change, thermal effluent discharges, or droughts, are more likely to be ecologically detrimental than gradual warming (Hastie et al. 2003, Mouthon and Daufresne 2006). Mussel population declines are most strongly associated with atypical conditions that extend beyond their normal tolerances (Golladay et al. 2004), and acute upper thermal limits might provide an indication of the extreme temperatures that mussels can tolerate in such circumstances. 
Mussels are among the most sensitive and rapidly declining faunal groups in North America and elsewhere in the world, and rising ambient temperatures and exposure to extreme thermal events could pose additional risks to threatened mussel species (Hastie et al. 2003). Of the $\sim 300$ freshwater mussel species native to North America, nearly $70 \%$ are extinct or vulnerable to extinction (Bogan 1993, Williams et al. 1993). This decline has been broadly attributed to pollution, water-quality degradation, and habitat destruction from anthropogenic influences. Specific causes of mussel declines are generally unknown but chronic, low-level stressors are presumed (Strayer et al. 2004, Cope et al. 2008). In addition, the unique life cycle of freshwater mussels makes them particularly susceptible to disruption by environmental stressors, such as temperature. Larval mussels (glochidia) infest the gills or fins of host fish as parasites before transforming into the juvenile life stage and dropping to the sediment to continue their development as benthicdwelling adults (e.g., Watters 2007).

Climate change might put mussels closer to their thermal limits, and additional heat inputs from thermal discharges, drought, or landuse changes could further alter the thermal environment of these sessile organisms. In the midwestern US, summer water temperatures can exceed $30^{\circ} \mathrm{C}$ (Otero-Benitez and Davis 2009), and temperatures in the southern US can reach 34 to $40^{\circ} \mathrm{C}$ (Dyar and Alhadeff 1997, Spooner and Vaughn 2008). To address thermal effects on larval and juvenile mussels, we determined the upper thermal tolerances for glochidia of 8 species and juveniles of 7 species representing 3 tribes of the Unionidae family (Graf and Cummings 2007). Mussels were held at 3 acclimation temperatures and tested over a range of experimental temperatures from 20 to $42^{\circ} \mathrm{C}$. These temperatures encompass the upper range of common and extreme temperatures encountered in rivers and streams in the US during the summer.

\section{Methods}

\section{Test organisms}

Eight species representing 3 tribes (Lampsilini, Anodontini, and Quadrulini) of the Unionidae family were used in our study (Graf and Cummings 2007): Lampsilis siliquoidea (Barnes), Potamilus alatus (Say), Ligumia recta (Lamarck), Ellipsaria lineolata (Rafinesque), Villosa delumbis (Conrad), Megalonaias nervosa (Rafinesque), Lasmigona complanata (Barnes), and Alasmidonta varicosa (Lamarck). All test organisms were propagated via host-fish infection in facilities at Missouri State University and North Carolina State

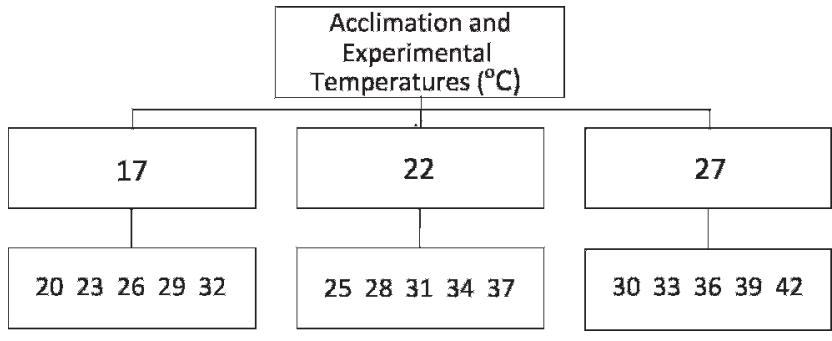

FIG. 1. Experimental design showing acclimation (20, 22, and $27^{\circ} \mathrm{C}$ ) and experimental temperature schemes for freshwater mussel tests. A nonacclimated $20^{\circ} \mathrm{C}$ control was included with each test.

University with standard propagation and culture methods (Barnhart 2006).

\section{Test conditions}

Glochidia and juvenile mussels were acclimated to 3 different temperatures $\left(17^{\circ} \mathrm{C}, 22^{\circ} \mathrm{C}\right.$, and $\left.27^{\circ} \mathrm{C}\right)$ and tested at 6 experimental temperatures (the acclimation temperature and 5 additional temperatures increased by $3^{\circ} \mathrm{C}$ increments) (Fig. 1). Unacclimated individuals maintained at $20^{\circ} \mathrm{C}$ (unacclimated control) were assessed side-by-side with individuals in experimental temperatures treatments within each acclimation temperature. Glochidia were $<24 \mathrm{~h}$ old at the start of each test. Glochidia were acclimated by adjusting their shipping temperature upon arrival by $1^{\circ} \mathrm{C} / \mathrm{h}$, with a 2-h acclimation period once the target temperature was reached. From January through April, shipping temperatures averaged $17^{\circ} \mathrm{C}\left( \pm 3^{\circ} \mathrm{C}\right)$, and from May through July shipping temperatures averaged $22^{\circ} \mathrm{C}\left( \pm 3^{\circ} \mathrm{C}\right)$. Tests were 24 -h nonaerated static experiments done in reconstituted hard water according to the American Society of Testing and Materials (ASTM) guidelines for glochidia (ASTM 2006a, b). Survival was assessed at $24 \mathrm{~h}$ for a subsample of $\sim 50$ of the 150 glochidia in each of 3 replicates per temperature. A saturated $\mathrm{NaCl}$ solution was used to stimulate a shell-closure response that was observed with an Olympus SZ61 microscope (Olympus America, Center Valley, Pennsylvania) and QCapture Pro 5.1 digital photographic software (Quantitative Imaging Corporation, Burnaby, British Columbia, Canada).

Juveniles of 7 mussel species were used to evaluate thermal sensitivity. Because of limited availability, $L$. complanata was omitted from juvenile testing, and $A$. varicosa was not tested at the $17^{\circ} \mathrm{C}$ acclimation temperature. Lampsilis siliquoidea, $P$. alatus, and $L$. recta individuals ranged in age from 3 to $8 \mathrm{wk}$. Shell lengths were $1386 \mu \mathrm{m}$ for L. siliquoidea, $1377 \mu \mathrm{m}$ for $P$. alatus, and $947 \mu \mathrm{m}$ for L. recta. Individuals of the 
remaining species (E. lineolata, M. nervosa, A. varicosa, and $V$. delumbis) ranged in age from $<1$ to $4 \mathrm{wk}$. Shell lengths were $335 \mu \mathrm{m}$ for E. lineolata, $364 \mu \mathrm{m}$ for $M$. nervosa, $398 \mu \mathrm{m}$ for A. varicosa, and $363 \mu \mathrm{m}$ for $V$. delumbis. Individuals within a species differed in age by 1 to 3 wk at most.

Juveniles were acclimated to the test acclimation temperature by adjusting their shipping temperature upon arrival by $2.5^{\circ} \mathrm{C} / \mathrm{d}$, with a $\geq 24 \mathrm{~h}$ acclimation period once the target temperature was attained. Experiments were 96-h nonaerated static renewal tests with $90 \%$ reconstituted hard water renewal at $48 \mathrm{~h}$. Tests were conducted according to ASTM guidelines for juveniles (ASTM 2006b). Survival was assessed visually with an Olympus SZ61 microscope to detect foot movement outside of the shell, foot movement within the shell, or the presence of a heart beat for the 7 mussels in each of 3 replicates per temperature. Controls had 10 mussels in each replicate.

Quality assurance and control were ensured by conducting all tests according to the Standard Guide for Conducting Laboratory Toxicity Tests with Freshwater Mussels (ASTM 2006b). Glochidial survival differed among species at the common control temperature $\left(20^{\circ} \mathrm{C}\right)$. Therefore, control survival was deemed acceptable for a species if it did not decrease substantially from initial survival at the start of the test (average decline in control survival from initial survival upon arrival in laboratory until 24-h assessment was $5.3 \%$, range $0-15.6 \%, n=24$ tests). Tests were conducted in light- and temperature-controlled environmental chambers (Precision Model 818, Thermo Electron Corp., Marietta, Ohio, and Isotemp Model 146E, Fisher Scientific, Dubuque, Iowa). National Institute of Standards and Technology (NIST)certified thermometers were used for daily temperature monitoring. Target test temperatures were $\pm 1^{\circ} \mathrm{C}$ $(n=866)$ for $98.6 \%$ of trials, with a maximum departure of $2^{\circ} \mathrm{C}$. Mean water-quality conditions across all tests were: $103.9 \mathrm{mg} \mathrm{CaCO}_{3} / \mathrm{L}$ alkalinity, $149.6 \mathrm{mg} \mathrm{CaCO} 3 / \mathrm{L}$ hardness, $564.2 \mu \mathrm{s} / \mathrm{cm}$ conductivity, $8.44 \mathrm{pH}$, and $7.28 \mathrm{mg} / \mathrm{L}$ dissolved $\mathrm{O}_{2}(n=27$ for alkalinity and hardness, $n=223$ for all other variables).

\section{Statistical analysis}

The effects of temperature treatments on mussels were analyzed with SAS Proc Mixed (version 9.1.3; SAS Institute Inc., Cary, North Carolina). The proportion of individuals that survived $\left(\mathrm{p}_{\text {surv }}\right)$ was $\arcsin (x)$ transformed before analysis. Significant temperature treatment effects $(p<0.05)$ were further analyzed through a pairwise comparison of differences in survival among the $20^{\circ} \mathrm{C}$ nonacclimated control and experimental temperatures within an acclimation temperature using Tukey's post hoc test.

The LT50 was defined as the temperature that caused mortality in $50 \%$ of the exposed population, and the LT05 was the temperature that caused mortality in 5\% of the exposed population. Survival data were used to generate LT50s and LT05s with logistic regression (Agresti 1996). $\mathrm{p}_{\text {surv }}$ was analyzed as the response variable, and species, acclimation temperature, and experimental temperature were the independent variables. The relationship between the experimental temperature and $\mathrm{p}_{\text {surv }}$ for a particular species at a given acclimation temperature (22 or $27^{\circ} \mathrm{C}$ ) was analyzed with a generalized linear model, assuming that $p_{\text {surv }}$ followed a Bernoulli distribution, and its logit was a linear function of the experimental temperatures. Differences between LT50 and LT05 values for both acclimation temperatures were analyzed for each species with a fixed-effect model that included acclimation temperature as a class variable and experimental temperature as a continuous variable. Survival curves and values of LT50 and LT05 for each curve and their differences were calculated with the SAS procedure NLMIXED.

\section{Results}

\section{Glochidia}

At the $17^{\circ} \mathrm{C}$ acclimation temperature, only $V$. delumbis were adversely affected by experimental temperatures (Fig. 2A). Survival at $32^{\circ} \mathrm{C}$ was significantly lower than survival at all other experimental temperatures and the $20^{\circ} \mathrm{C}$ control $(p<0.0001)$.

At the $22^{\circ} \mathrm{C}$ acclimation temperature, survival of $L$. siliquoidea was similar at all experimental temperatures and the $20^{\circ} \mathrm{C}$ control (all $p>0.05$; Fig. 3A). Survival of L. complanata and $A$. varicosa was significantly lower at $37^{\circ} \mathrm{C}$ than at all other experimental temperatures and in the $20^{\circ} \mathrm{C}$ control $(p<0.0001)$. Ellipsaria lineolata survival was significantly lower at $34^{\circ} \mathrm{C}$ and $37^{\circ} \mathrm{C}$ than at all other experimental temperatures and in the $20^{\circ} \mathrm{C}$ control $(p<0.0001)$, and survival of $M$. nervosa was significantly lower at 31,34 , and $37^{\circ} \mathrm{C}$ than in all other experimental temperatures and in the $20^{\circ} \mathrm{C}$ control (all $p<0.0001$, except $M$. nervosa $31^{\circ} \mathrm{C} p=0.0132$ ). Ligumia recta survival was significantly lower at $31^{\circ} \mathrm{C}(p=$ 0.0160 ) than at 22 and $28^{\circ} \mathrm{C}$ and in the $20^{\circ} \mathrm{C}$ control and lower at $37^{\circ} \mathrm{C}(p<0.0001)$ than at 22,25 , and $28^{\circ} \mathrm{C}$ and in the $20^{\circ} \mathrm{C}$ control, and $P$. alatus survival was lower at $28(p=0.0003), 31,34$, and $37^{\circ} \mathrm{C}$ (all $\left.p<0.0001\right)$ than in the $20^{\circ} \mathrm{C}$ control. Villosa delumbis survival was significantly lower at $31^{\circ} \mathrm{C}(p<0.0001)$ than in the $20^{\circ} \mathrm{C}$ control and lower at 34 and $37^{\circ} \mathrm{C}$ (all $\left.p<0.0001\right)$ than at 22,25 , and $28^{\circ} \mathrm{C}$ and in the $20^{\circ} \mathrm{C}$ control. 


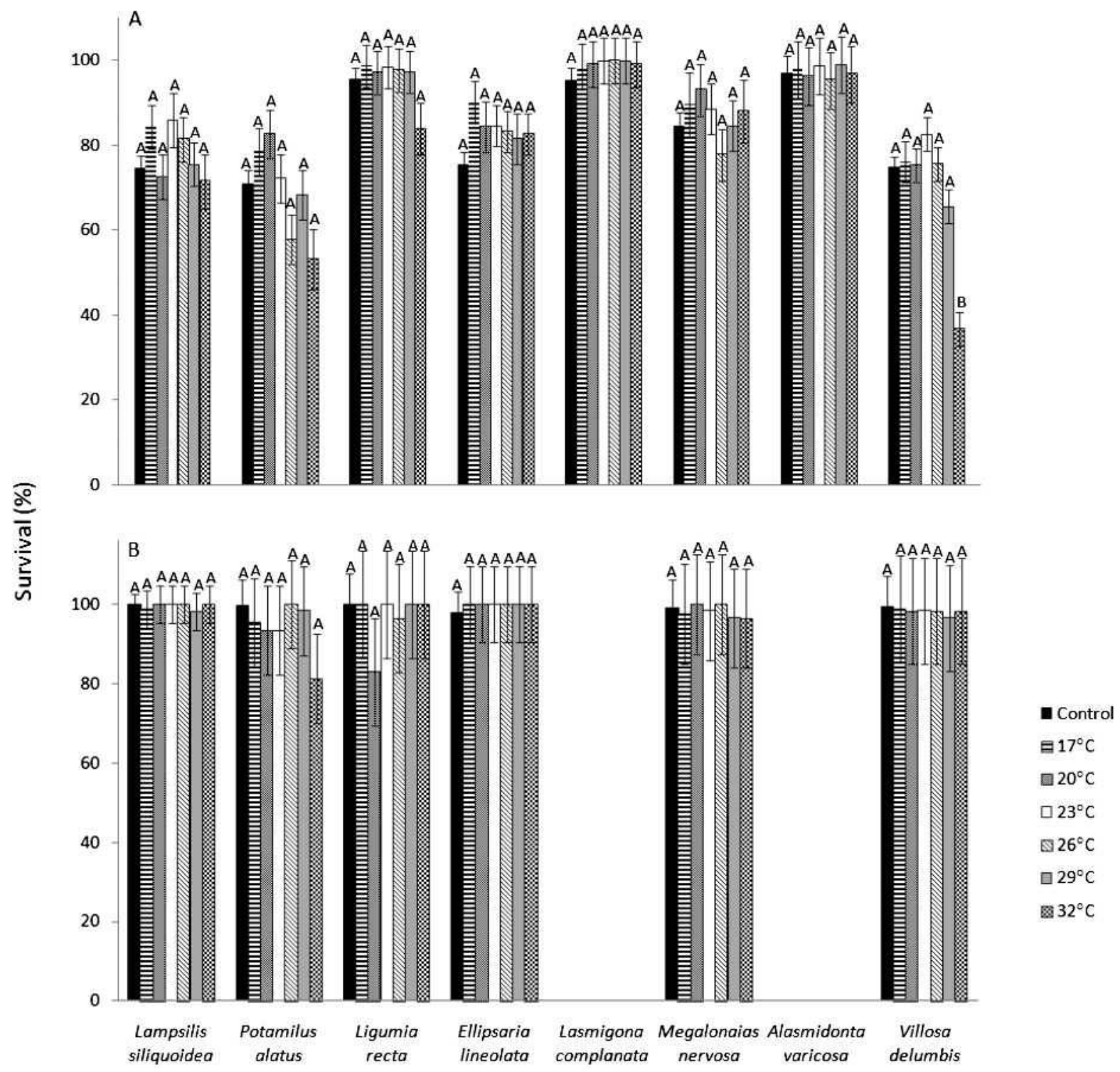

Species

FIG. 2. Mean ( $\pm 1 \mathrm{SE}, n=3$ ) survival of glochidia of 8 species (A) and juveniles of 6 species (B) of freshwater mussels held at an acclimation temperature of $17^{\circ} \mathrm{C}$ and subjected to 6 experimental temperatures $\left(17,20,23,26,29\right.$, and $\left.32^{\circ} \mathrm{C}\right)$ or held in a nonacclimated $20^{\circ} \mathrm{C}$ control. Bars representing temperature treatments within a species with the same uppercase letters are not significantly different $(p>0.05)$.

At the $27^{\circ} \mathrm{C}$ acclimation temperature (Fig. $4 \mathrm{~A}$ ), L. siliquoidea and $\mathrm{L}$. complanata had significantly lower survival at $39^{\circ} \mathrm{C}$ and $42^{\circ} \mathrm{C}$ than at any other experimental temperature and in the $20^{\circ} \mathrm{C}$ control $(p$ $<0.0001)$. Alasmidonta varicosa survival was significantly lower at $36^{\circ} \mathrm{C}(p=0.0046)$ than in the $20^{\circ} \mathrm{C}$ control and lower at 39 and $42^{\circ} \mathrm{C}(p<0.0001)$ than in all other experimental temperatures and in the $20^{\circ} \mathrm{C}$ control. Survival of L. recta, was significantly lower at
33 and $36^{\circ} \mathrm{C}$ than in the $20^{\circ} \mathrm{C}$ control or at 27 and $30^{\circ} \mathrm{C}$ and lower at 39 and $42^{\circ} \mathrm{C}$ than in all other experimental temperatures and the $20^{\circ} \mathrm{C}$ control (all $p<$ 0.0001). Megalonaias nervosa survival was significantly lower at $27^{\circ} \mathrm{C}(p=0.0128)$ and $33^{\circ} \mathrm{C}$ than in the $20^{\circ} \mathrm{C}$ control and was lower at 36,39 , and $42^{\circ} \mathrm{C}$ (all $p<$ $0.0001)$ than at all other experimental temperatures and in the $20^{\circ} \mathrm{C}$ control. Survival of $V$. delumbis was significantly lower at all temperatures except $30^{\circ} \mathrm{C}$ 


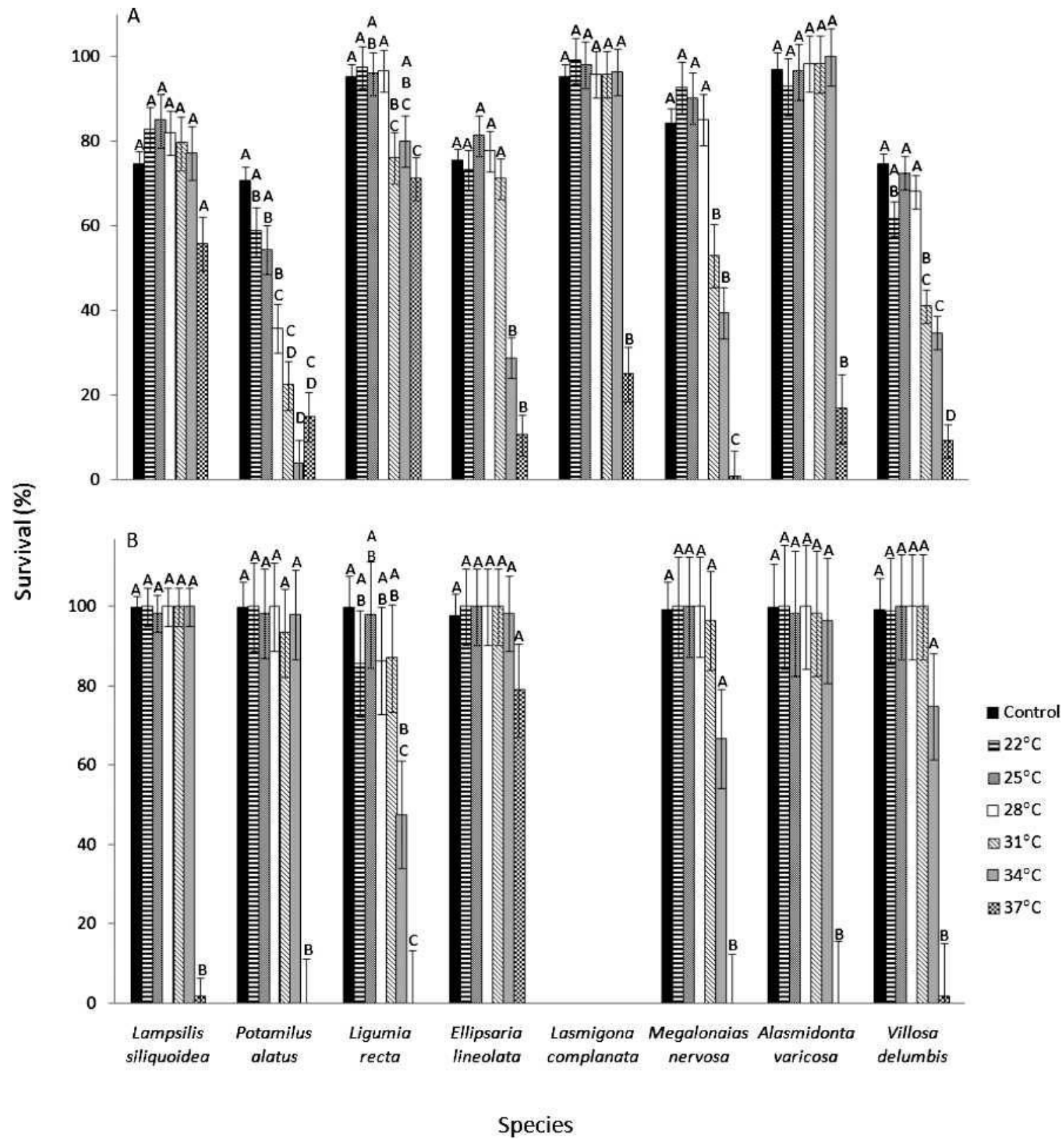

FIG. 3. Mean ( $\pm 1 \mathrm{SE}, n=3$ ) survival of glochidia of 8 species (A) and juveniles of 6 species (B) of freshwater mussels held at an acclimation temperature of $22^{\circ} \mathrm{C}$ and subjected to 6 experimental temperatures $\left(22,25,28,31,34\right.$, and $\left.37^{\circ} \mathrm{C}\right)$ or held in a nonacclimated $20^{\circ} \mathrm{C}$ control. Bars representing temperature treatments within a species with the same uppercase letters are not significantly different $(p>0.05)$.

than in the $20^{\circ} \mathrm{C}$ control $(p<0.0001)$ and lower at $39^{\circ} \mathrm{C}$ and $42^{\circ} \mathrm{C}$ than in all other experimental temperatures (all $p<0.0001$ ). Potamilus alatus and E. lineolata were the most thermally sensitive species, with survival significantly lower at all experimental temperatures than in the $20^{\circ} \mathrm{C}$ control $(p<0.0001)$. Significant decreases in survival relative to in the $20^{\circ} \mathrm{C}$ control at the $27^{\circ} \mathrm{C}$ acclimation temperature and not at the 17 or $22^{\circ} \mathrm{C}$ acclimation temperatures for $P$. alatus, E. line- olata, M. nervosa, and $V$. delumbis were not indicative of an acclimation effect. The $27^{\circ} \mathrm{C}$ temperature caused significant mortality in these 4 species because, unlike the other 2 temperatures, it was essentially a temperature treatment rather than an acclimation temperature.

Alasmidonta varicosa generally re-opened $\sim 1 \mathrm{~min}$ after initial shell closure when $\mathrm{NaCl}$ was added. For this reason, $A$. varicosa is not recommended as a 


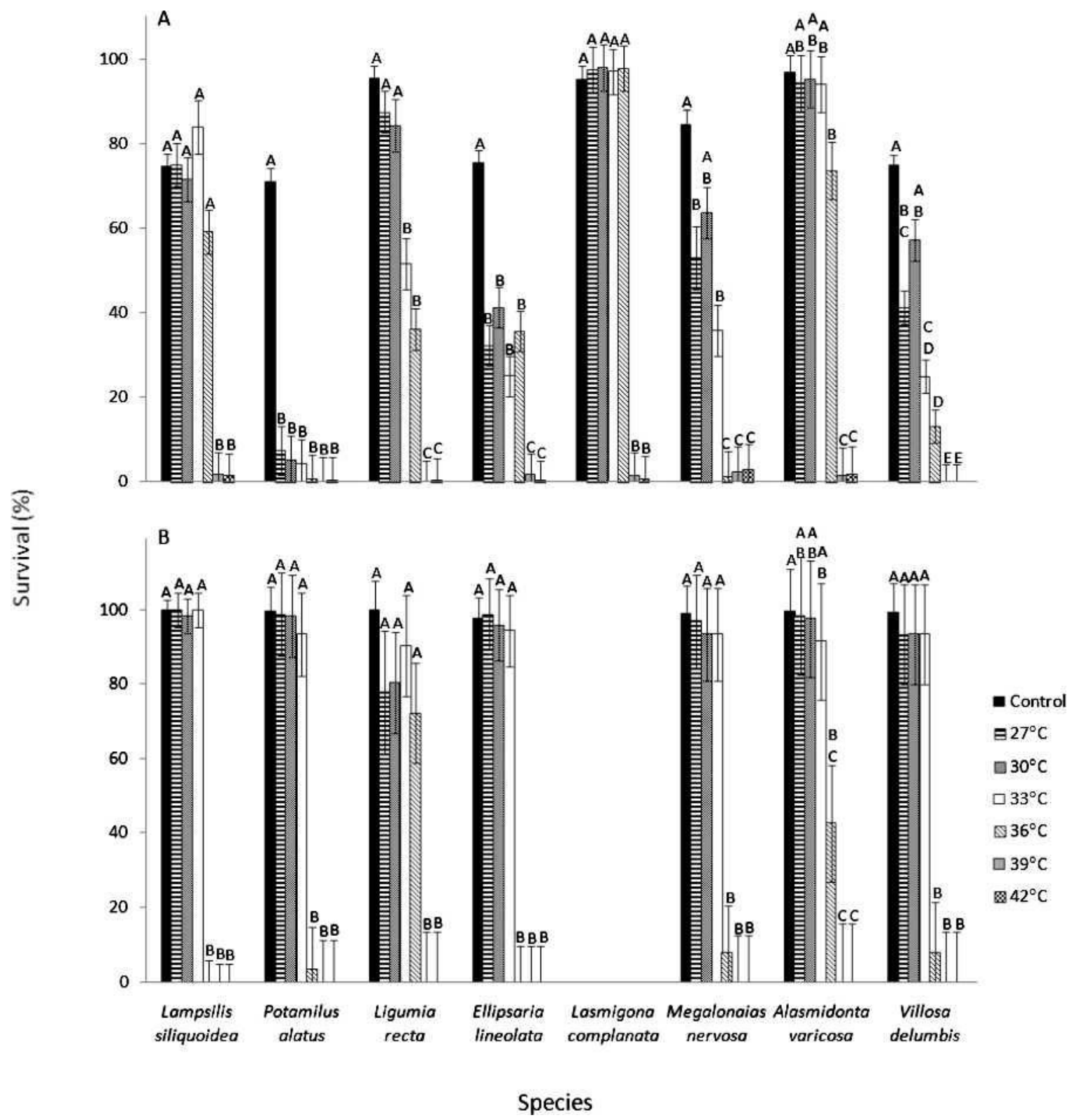

FIG. 4. Mean ( $\pm 1 \mathrm{SE}, n=3$ ) survival of glochidia of 8 species (A) and juveniles of 6 species (B) of freshwater mussels held at an acclimation temperature of $27^{\circ} \mathrm{C}$ and subjected to 6 experimental temperatures $\left(27,30,33,36,39\right.$, and $\left.42^{\circ} \mathrm{C}\right)$ or held in a nonacclimated $20^{\circ} \mathrm{C}$ control. Bars representing temperature treatments within a species with the same uppercase letters are not significantly different $(p>0.05)$.

model species in laboratory testing with glochidia unless photographs can be taken immediately after $\mathrm{NaCl}$ addition.

\section{Juveniles}

At the $17^{\circ} \mathrm{C}$ acclimation temperature, survival of all species was similar among all experimental temperatures $(p>0.05$; Fig. $2 \mathrm{~B})$. At the $22^{\circ} \mathrm{C}$ acclimation temperature, survival of E. lineolata did not differ significantly among experimental temperatures $(p>$ 0.05; Fig. 3B). Survival of $L$. siliquoidea, P. alatus, $M$. nervosa, $A$. varicosa, and $V$. delumbis was significantly lower at $37^{\circ} \mathrm{C}$ than at any other experimental temperature and the $20^{\circ} \mathrm{C}$ control $(p<0.0001$ for all species), and survival was similar at all other experimental temperatures. Survival of L. recta was significantly lower at $34^{\circ} \mathrm{C}(p=0.0020)$ than in the $20^{\circ} \mathrm{C}$ control and lower at $37^{\circ} \mathrm{C}$ (all $\left.p<0.0001\right)$ than at $22,25,28$, and $31^{\circ} \mathrm{C}$ and in the $20^{\circ} \mathrm{C}$ control. 
At the $27^{\circ} \mathrm{C}$ acclimation temperature, mortality for all species was $100 \%$ at 39 and $42^{\circ} \mathrm{C}(p<0.0001$ for all species; Fig. 4B). Survival of L. recta did not differ among all other experimental temperatures or in the $20^{\circ} \mathrm{C}$ control, whereas survival of $L$. siliquoidea, $P$. alatus, E. lineolata, $M$. nervosa, and $V$. delumbis also was significantly lower at $36^{\circ} \mathrm{C}$ than at lower experimental temperatures and in the $20^{\circ} \mathrm{C}$ control $(p<0.0001$ for all species). Alasmidonta varicosa survival was lower at $36^{\circ} \mathrm{C}(p=0.0120)$ than in the $20^{\circ} \mathrm{C}$ control, but similar to survival at 27,30 , and $33^{\circ} \mathrm{C}$ (all $p>0.05$ ).

\section{Thermal tolerance}

LT50s for glochidia $(24 \mathrm{~h})$ and juvenile $(96 \mathrm{~h})$ freshwater mussels were calculated for the 22 and $27^{\circ} \mathrm{C}$ acclimation temperatures (Table 1 ) but not for the $17^{\circ} \mathrm{C}$ acclimation temperature because of lack of sufficient mortalities. Overall mean LT50s ranged from 21.4 to $42.6^{\circ} \mathrm{C}$ with a mean of $33.1^{\circ} \mathrm{C}$. Glochidial LT50s ranged from 21.4 to $42.6^{\circ} \mathrm{C}$ with a mean of $31.6^{\circ} \mathrm{C}$. No differences in thermal tolerance were associated with change in acclimation temperature, but thermal tolerances did differ among some species (Table 1). At the $22^{\circ} \mathrm{C}$ acclimation temperature, $P$. alatus had a significantly lower LT50 than L. complanata and A. varicosa. At the $27^{\circ} \mathrm{C}$ acclimation temperature, $P$. alatus had a significantly lower LT50 than $L$. siliquoidea and L. recta. Juvenile LT50s ranged from 32.5 to $38.8^{\circ} \mathrm{C}$ with a mean of $34.7^{\circ} \mathrm{C}$. No changes in thermal tolerance were associated with acclimation temperature, and juvenile LT50s did not differ among species. LT50s differed between glochidia and juveniles for $P$. alatus, and juveniles were significantly more thermally tolerant than glochidia at the $22^{\circ} \mathrm{C}(p$ $=0.0029)$ and $27^{\circ} \mathrm{C}(p=0.0004)$ acclimation temperatures. Juvenile $V$. delumbis were more thermally tolerant than $V$. delumbis glochidia at the $27^{\circ} \mathrm{C}$ acclimation temperature ( $p=0.0334)$. Thermal tolerances did not differ between life stages for any other species $(p>0.05)$.

Overall LT05s for glochidia $(24 \mathrm{~h})$ and juvenile mussels $(96 \mathrm{~h})$ at the 22 and $27^{\circ} \mathrm{C}$ acclimation temperatures ranged from 15.6 to $34.1^{\circ} \mathrm{C}$ with a mean of $27.8^{\circ} \mathrm{C}$ (Table 1). Glochidia LT05s ranged from 15.6 to $30.3^{\circ} \mathrm{C}$ with a mean of $25.0^{\circ} \mathrm{C}$. Juvenile LT05s ranged from 23.7 to $34.1^{\circ} \mathrm{C}$ with a mean of $29.4^{\circ} \mathrm{C}$. At the $22^{\circ} \mathrm{C}$ acclimation temperature, LT05s differed between juveniles of $L$. recta and E. lineolata, but tolerances did not differ between glochidia or juveniles of any other species (Table 1). No changes in LT05s were associated with acclimation temperature for glochidia or juveniles. For the 3 species with LT05 data, values did not differ between life stages (all $p>0.05$ ). The average difference between LT50 and LT05 was $10.6^{\circ} \mathrm{C}\left(6.8-19.1^{\circ} \mathrm{C}\right)$ for glochidia and $5.3^{\circ} \mathrm{C}\left(1.9-8.8^{\circ} \mathrm{C}\right)$ for juveniles within a species. Thus, a temperature increase of $10.6^{\circ} \mathrm{C}$ theoretically could reduce the survival of an average population of glochidia from 95\% to only 50\% survival, and a temperature increase of only $5.3^{\circ} \mathrm{C}$ could have the same consequence in an average population of juveniles.

\section{Discussion}

We are the first to report acute lethal thermal tolerances for the early life stages of a range of freshwater mussel species. Our results show that small increases in temperature can lead to significant reductions in survival of freshwater mussels. Dimock and Wright (1993) reported a $96-\mathrm{h}$ LT50 of $31.5^{\circ} \mathrm{C}$ for 1-wk-old juvenile Utterbackia imbecillis (Say) and $33^{\circ} \mathrm{C}$ for 1-wk-old Pyganodon cataracta (Say) in the only other published study of acute thermal tolerances of early life stages of freshwater mussels. These results are similar to the results for juveniles in our study.

Acclimation temperature did not affect thermal tolerance in freshwater mussels. The acclimation period that we used was longer and more conservative than the $3^{\circ} \mathrm{C} / \mathrm{h}$ temperature change recommended in the ASTM mussel testing guide (ASTM 2006b), but it might have been too short to establish a true acclimation (Ansell et al. 1980a). In a review of thermal tolerance studies for 50 aquatic species, de Vries et al. (2008) reported that acclimation periods generally exceeded $96 \mathrm{~h}$. Future tests with a longer acclimation period might help determine any latent effect of acclimation on thermal tolerance of juvenile mussels.

Freshwater mussel species respond uniquely to different thermal regimes, and these differences correspond with variable filtration and excretion rates. Therefore, changes in thermal regime that alter species composition can affect ecological processes (Spooner and Vaughn 2008, 2009, Vaughn et al. 2008). We found significant differences in glochidial LT50s among species, but no differences in juvenile LT50s among species. In contrast, we found differences in juvenile LT05s between 2 species, but no differences in glochidial LT05s among species. The relatively wide range of LT50s for glochidia might be attributable to the fact that survival of this life stage is variable among species, even within the range of thermal tolerance (Zimmerman and Neves 2002, Cope et al. 2008). Morphological characteristics and traitbased differences might play a role in the different thermal tolerances among adults of different species 
TABLE 1. Experimental temperatures causing 50\% (LT50) and 5\% (LT05) mortality (with 95\% confidence intervals) in glochidia $(24 \mathrm{~h})$ and juvenile $(96 \mathrm{~h})$ mussels at 22 and $27^{\circ} \mathrm{C}$ acclimation temperatures. LT50 or LT05 values among species within a life stage and acclimation temperature with the same letters are not significantly different $(p>0.05)$. ND = value could not be determined, * = no test run for Lasmigona complanata juveniles.

\begin{tabular}{|c|c|c|c|c|c|c|c|c|}
\hline \multirow[b]{2}{*}{ Species } & \multicolumn{4}{|c|}{ LT50 } & \multicolumn{4}{|c|}{ LT05 } \\
\hline & Glochidia & Juveniles & Glochidia & Juveniles & Glochidia & Juveniles & Glochidia & Juveniles \\
\hline $\begin{array}{l}\text { Lampsilis } \\
\quad \text { siliquoidea }\end{array}$ & ND & $\begin{array}{c}35.6 \mathrm{~A} \\
(32.8-38.3)\end{array}$ & $\begin{array}{c}32.8 \mathrm{AC} \\
(26.7-38.8)\end{array}$ & $\begin{array}{c}34.4 \mathrm{~A} \\
(32.3-36.5)\end{array}$ & $\mathrm{ND}$ & $\begin{array}{c}31.3 \mathrm{AB} \\
(26.2-36.3)\end{array}$ & ND & $\begin{array}{c}32.5 \mathrm{~A} \\
(29.7-35.3)\end{array}$ \\
\hline $\begin{array}{l}\text { Potamilus } \\
\text { alatus }\end{array}$ & $\begin{array}{c}24.2 \mathrm{~A} \\
(17.7-30.6)\end{array}$ & $\begin{array}{c}35.0 \mathrm{~A} \\
(32.6-37.4)\end{array}$ & $\begin{array}{c}21.4 \mathrm{~B} \\
(15.4-27.5)\end{array}$ & $\begin{array}{c}34.1 \mathrm{~A} \\
(31.4-36.7)\end{array}$ & ND & $\begin{array}{c}31.2 \mathrm{AB} \\
(26.7-35.8)\end{array}$ & ND & $\begin{array}{c}28.8 \mathrm{~A} \\
(23.4-34.1)\end{array}$ \\
\hline $\begin{array}{l}\text { Ellipsaria } \\
\quad \text { lineolata }\end{array}$ & $\begin{array}{c}31.0 \mathrm{AB} \\
(24.8-37.2)\end{array}$ & $\begin{array}{c}38.8 \mathrm{~A} \\
(30.5-47.2)\end{array}$ & $\begin{array}{c}25.7 \mathrm{BC} \\
(17.2-34.2)\end{array}$ & $\begin{array}{c}33.1 \mathrm{~A} \\
(30.0-36.3)\end{array}$ & ND & $\begin{array}{c}34.1 \mathrm{~B} \\
(27.4-40.7)\end{array}$ & ND & $\begin{array}{c}26.4 \mathrm{~A} \\
(19.8-33.0)\end{array}$ \\
\hline $\begin{array}{l}\text { Lasmigona } \\
\quad \text { complanata }\end{array}$ & $\begin{array}{c}37.8 \mathrm{~B} \\
(29.4-46.3)\end{array}$ & $*$ & $\begin{array}{c}37.1 \mathrm{~A} \\
(34.0-40.2)\end{array}$ & * & $\begin{array}{c}27.9 \mathrm{~A} \\
(18.9-36.9)\end{array}$ & * & $\begin{array}{c}30.3 \mathrm{~A} \\
(24.0-36.7)\end{array}$ & * \\
\hline $\begin{array}{c}\text { Megalonaias } \\
\text { nervosa }\end{array}$ & $\begin{array}{c}31.3 \mathrm{AB} \\
(26.9-35.6)\end{array}$ & $\begin{array}{c}34.2 \mathrm{~A} \\
(31.7-36.6)\end{array}$ & $\begin{array}{c}28.4 \mathrm{BC} \\
(22.7-34.2)\end{array}$ & $\begin{array}{c}34.0 \mathrm{~A} \\
(30.9-37.1)\end{array}$ & $\begin{array}{c}20.9 \mathrm{~A} \\
(12.1-29.8)\end{array}$ & $\begin{array}{c}30.0 \mathrm{AB} \\
(25.2-34.8)\end{array}$ & $\begin{array}{c}15.6 \mathrm{~A} \\
(0.7-30.5)\end{array}$ & $\begin{array}{c}27.2 \mathrm{~A} \\
(20.7-33.7)\end{array}$ \\
\hline
\end{tabular}

(Bartsch et al. 2000, Spooner and Vaughn 2008). Characteristics like shell shape, thickness, size, or physiology do not necessarily pertain to newly transformed juvenile mussels, but their influence should be investigated in future studies.

Acclimatization to environmental conditions occurs over time, so normal temperatures in an animal's natural habitat are rarely harmful (Ansell et al. 1980a). However, extreme thermal events can cause significant changes in aquatic community structure in relatively short amounts of time, and mollusk communities might be slow to recover if they have already experienced a gradual warming of their environment (Mouthon and Daufresne 2006). Summer maximum water temperatures in the US are variable but can range from $25^{\circ} \mathrm{C}$ in the upper midwest to $34-40^{\circ} \mathrm{C}$ in the south (Wellborn and Robinson 1996, Dyar and Alhadeff 1997, Wright et al. 1999, Spooner and Vaughn 2008). The chances of extreme thermal events increase in summer when the natural heat load can be increased by a variety of factors (Durrett and Pearson 1975, Ansell et al. 1980b, Parkin and Stahl 1981). For example, low flow conditions in an Oklahoma river produced temperatures that frequently ranged from 34 to $38^{\circ} \mathrm{C}$ (Schaefer et al. 2003), and thermal effluents from industry can increase the temperature of receiving waters by 4 to $8^{\circ} \mathrm{C}$ (Wellborn and Robinson 1996, Cooke et al. 2004, Encina et al. 2008). These temperatures are close to, or above, the upper thermal tolerances for the early life stages of freshwater mussels (this study).

On average, the difference between the LT50 and the LT05 of juveniles within a given species was only $5.3^{\circ} \mathrm{C}$, and the difference was only $10.6^{\circ} \mathrm{C}$ for glochidia of a given species. Over this relatively narrow span of temperatures, mortality in a mussel population could theoretically increase from 5\% to 50\%. However, mortality is not the only consequence of increased temperatures. The LT05s calculated in our study represent temperatures that are high enough to cause sublethal effects, such as changes in filtration rate or immune response, in bivalves (Chen et al. 2007, Loayza-Muro and Elias-Letts 2007). Warm temperatures create a higher demand on metabolic energy and can interfere with behavior, maintenance, and reproductive processes (Dudgeon and Morton 1984, Parker et al. 1984, Weaver et al. 1991, Roberts and Barnhart 1999, Bartsch et al. 2000). Temperature shifts can alter timing of reproduction (Barnett 1972), leading to decreased fertilization and recruitment success (Walther et al. 2002, Philippart et al. 2003). Changing temperatures also can lead to asynchrony, a mismatch between life-history events and environmental conditions (Visser and Holleman 2001, Philippart et al. 2003). For example, a mismatch between the timing of gravidity and glochidial release and the presence of necessary host fish could inhibit freshwater mussel reproduction. 
Freshwater mussels are likely to encounter rising environmental temperatures from climate change, thermal effluents, drought, or landuse changes. Species living closest to their thermal limits might be most susceptible to changes in environmental temperatures (Tomanek and Somero 1999, Stillman 2003), and we have demonstrated that temperatures sometimes encountered in freshwater mussel habitat during summer in the temperate US are close to or above the upper thermal tolerances of early life stages of freshwater mussels. Mussels are exposed to a range of stressors, both chemical and nonchemical, and a bivalve that has already been weakened by thermal stress might be more susceptible to other adverse conditions (Sokolova 2004). Water-quality criteria should be developed with the understanding that thermal stress can arise from multiple sources simultaneously and can interact with other stressors. A single heat source might not be detrimental to aquatic organisms, but cumulative effects of combined inputs might be.

Freshwater mussels already are among the most imperiled organisms in the world, so it is crucial to identify the factors that contribute to population declines. Management of freshwater mussel populations can be difficult because mussel populations can persist under conditions of negative growth and appear stable when they are not (Strayer et al. 2004). Freshwater mussels are sedentary animals and must be able to tolerate local environmental conditions to survive. Because they are long-lived, recovery or establishment of populations might require more time than the interval between anthropogenic stressors. Therefore, some mussels might require direct management and human involvement via conservation, augmentation, translocation, or captive breeding (Hastie et al. 2003, Strayer et al. 2004). Habitat restoration, the creation of thermal buffers in riparian zones, and management strategies designed to maintain adequate flows during critical life-history periods could mediate some effects of increased temperatures and might restore entire communities (Hastie et al. 2003).

\section{Acknowledgements}

Funding for this research was provided by the US Environmental Protection Agency (EPA) grant agreement number DW-14-94814301 to WGC. The views expressed in this article do not necessarily represent the views of the US EPA. We thank Chris Eads and Renae Greiner at the North Carolina State University College of Veterinary Medicine for providing Atlantic Slope mussel species. We thank Andrea Crownhart and Michael Pillow of Missouri State University for assistance in providing Interior Basin test organisms.

\section{Literature Cited}

Agresti, A. 1996. An introduction to categorical data analysis. John Wiley and Sons, New York.

AKIYAma, Y., and T. Inakuma. 2007. Survival of glochidial larvae of the freshwater pearl mussel, Margaritifera laevis (Bivalvia: Unionoida), at different temperatures: a comparison between two populations with and without recruitment. Zoological Science 24:890-893.

Ansell, A. D., P. R. Barnett, A. Bodoy, And H. Masse. 1980a. Upper temperature tolerance of some European molluscs. II. Donax vittatus, D. semistriatus and D. trunculus. Marine Biology 58:41-46.

Ansell, A. D., P. R. O. Barnett, A. Bodoy, and H. Masse. 1980b. Upper temperature tolerance of some European molluscs. I. Tellina fabula and T. tenuis. Marine Biology 58:33-39.

ASTM (American Society of Testing and Materials). 2006a. Standard guide for conducting acute toxicity tests with fishes, macroinvertebrates, and amphibians. E729-88a. ASTM International, West Conshohocken, Pennsylvania.

ASTM (American Society of Testing and Materials). 2006b. Standard guide for conducting laboratory toxicity tests with freshwater mussels. E2455-06. ASTM International, West Conshohocken, Pennsylvania.

BARNETT, P. R. O. 1972. Effects of warm water effluents from power stations on marine life. Proceedings of the Roval Societv of London Series B: Biological Sciences 180: 497-509.

BARNHART, M. C. 2006. Buckets of muckets: a compact system for rearing juvenile freshwater mussels. Aquaculture 254:227-233.

Bartsch, M. R., D. L. Waller, W. G. Cope, and S. Gutreuter. 2000. Emersion and thermal tolerances of three species of unionid mussels: survival and behavioral effects. Journal of Shellfish Research 19:233-240.

Beitinger, T. L., W. A. Bennett, and R. W. McCauley. 2000. Temperature tolerances of North American freshwater fishes exposed to dynamic changes in temperature. Environmental Biology of Fishes 58:237-275.

BogAN, A. E. 1993. Freshwater bivalve extinctions: search for a cause. American Zoologist 33:599-609.

Chen, M., H. Yang, M. Delaporte, and S. Zhao. 2007. Immune condition of Chlamys farreri in response to acute temperature challenge. Aquaculture 271:479-487.

COOKe, S. J., C. M. Bunt, AND J. F. SChreer. 2004. Understanding fish behavior, distribution, and survival in thermal effluents using fixed telemetry arrays: a case study of smallmouth bass in a discharge canal during winter. Environmental Management 33:140-150.

Cope, W. G., R. B. Bringolf, D. B. Buchwalter, T. J. Newton, C. G. Ingersoll, N. Wang, T. Augspurger, F. J. Dwyer, M. C. Barnhart, R. J. Neves, and E. Hammer. 2008. Differential exposure, duration, and sensitivity of unionoidean bivalve life stages to environmental con- 
taminants. Iournal of the North American Benthological Society 27:451-462.

Daufresne, M., M. C. Roger, H. Capra, and N. Lamouroux. 2003. Long-term changes within the invertebrate and fish communities of the Upper Rhone River: effects of climatic factors. Global Change Biology 10:124-140.

de Vries, P., J. E. Tamis, A. J. Murk, and M. G. D. Smit. 2008. Development and application of a species sensitivity distribution for temperature-induced mortality in the aquatic environment. Environmental Toxicology and Chemistry 27:2591-2598.

Dimock, R. V., AND A. H. WRight. 1993. Sensitivity of juvenile freshwater mussels to hypoxic, thermal, and acid stress. Journal of the Elisha Mitchell Scientific Society 109: 183-192.

Dudgeon, D., And B. Morton. 1984. Site determination and attachment duration of Anodonta woodiana (Bivalvia: Unionacea) glochidia on fish hosts. Iournal of Zoology. London 204:355-362.

Durrett, C. W., AND W. D. Pearson. 1975. Drift of macroinvertebrates in a channel carrying heated water from a power plant. Hvdrobiologia 46:33-43.

Dyar, T. R., and S. J. Alhadeff. 1997. Stream-temperature characteristics in Georgia. Water-Resources Investigations Report 96-4203. US Geological Survey, Atlanta, Georgia.

EAton, J. G., And R. M. Scheller. 1996. Effects of climate warming on fish thermal habitat in streams of the United States. Limnology and Oceanography 41:1109-1115.

Encina, L., A. Rodriguez-Ruiz, and C. Granado-Lorencio. 2008. Distribution of common carp in a Spanish reservoir in relation to thermal loading from a nuclear power plant. Iournal of Thermal Biology 33:444-450.

Golladay, S. W., P. Gagnon, M. Kearns, J. M. Battle, and D. W. HicKS. 2004. Response of freshwater mussel assemblages (Bivalvia:Unionidae) to a record drought in the Gulf Coastal Plain of southwestern Georgia. Iournal of the North American Benthological Society 23:494-506.

Graf, D. L., AND K. S. Cummings. 2007. Review of the systematics and global diversity of freshwater mussel species (Bivalvia: Unionoida). Iournal of Molluscan Studies 73:291-314.

Hastie, L. C., P. J. Cosgrove, N. Ellis, and M. J. Gaywood. 2003. The threat of climate change to freshwater pearl mussel populations. Ambio 32:40-46.

Jansen, W., G. Bauer, and E. Zahner-Meike. 2001. Glochidia mortality in freshwater mussels. Pages 185-211 in G. Bauer and K. Wachtler (editors). Ecology and evolution of the freshwater mussels Unionoida. Springer-Verlag, Berlin, Germany.

Kinouchi, T., H. Yagi, and M. Miyamoto. 2007. Increase in stream temperature related to anthropogenic heat input from urban wastewater. Iournal of Hvdrology 335: 78-88.

LoAyza-Muro, R., AND R. Elias-Letts. 2007. Responses of the mussel Anodontites trapesialis (Unionidae) to environmental stressors: effect of $\mathrm{pH}$, temperature and metals on filtration rate. Environmental Pollution 149:209-215.
Mohseni, O., H. G. Stefan, and J. G. Eaton. 2003. Global warming and potential changes in fish habitat in U.S. Streams. Climatic Change 59:389-409.

Mouthon, J., AND M. Daufresne. 2006. Effects of the 2003 heatwave and climatic warming on mollusc communities of the Saone: a large lowland river and of its two main tributaries (France). Global Change Biology 12: 441-449.

Otero-BeniteZ, W., AND J. V. DAvis. 2009. Quality of surface water in Missouri, water year 2007. Open-file Report 2009-1096. US Geological Survey, Reston, Virginia.

PARKer, R. S., C. T. HACKNEY, AND M. F. VidRINE. 1984. Ecology and reproductive strategy of a south Louisiana freshwater mussel, Glebula rotundata (Lamarck) (Unionidae: Lampsilini). Freshwater Invertebrate Biology 3:53-58.

PARKIN, R. B., AND J. B. STAHL. 1981. Chironomidae (Diptera) of Baldwin Lake, Illinois, a cooling reservoir. Hydrobiologia 76:119-128.

Philippart, C. J. M., H. M. van Aken, J. J. Beukema, O. G. Bos, G. C. CADEE, AND R. DeKKer. 2003. Climate-related changes in recruitment of the bivalve Macoma balthica. Limnologv and Oceanography 48:2171-2185.

Roberts, A. D., AND M. C. BARnhart. 1999. Effects of temperature, $\mathrm{pH}$, and $\mathrm{CO}_{2}$ on transformation of the glochidia of Anodonta suborbiculata on fish hosts and in vitro. Iournal of the North American Benthological Society 18:477-487.

Schaefer, J. F., E. Marsh-Matthews, D. E. Spooner, K. B. GIDO, AND W. J. Matthews. 2003. Effects of barriers and thermal refugia on local movement of the threatened leopard darter, Percina pantherina. Environmental Biologv of Fishes 66:391-400.

SoKolova, I. M. 2004. Cadmium effects on mitochondrial function are enhanced by elevated temperatures in a marine ectotherm, Crassostrea virginica Gmelin (Bivalvia: Ostreidae). Iournal of Experimental Biology 207: 2639-2648.

SpoOner, D. E., AND C. C. VAughn. 2008. A trait-based approach to species' roles in stream ecosystems: climate change, community structure, and material cycling. Oecologia (Berlin) 158:307-317.

SpoOner, D. E., AND C. C. VAughn. 2009. Species richness and temperature influence mussel biomass: a partitioning approach applied to natural communities. Ecology 90: 781-790.

Stillman, J. H. 2003. Acclimation capacity underlies susceptibility to climate change. Science 301:65.

Strayer, D. L., J. A. Downing, W. R. HaAg, T. L. King, J. B. Layzer, T. J. Newton, AND S. Jerrine Nichols. 2004. Changing perspectives on pearly mussels, North America's most imperiled animals. BioScience 54:429-439.

TomaneK, L., And G. N. Somero. 1999. Evolutionary and acclimation-induced variation in the heat-shock responses of congeneric marine snails (genus Tegula) from different thermal habitats: implications for limits of thermotolerance and biogeography. Iournal of Experimental Biology 202:2925-2936.

Vaughn, C. C., S. J. Nichols, and D. E. Spooner. 2008. Community and foodweb ecology of freshwater mus- 
sels. Iournal of the North American Benthological Society 27:409-423.

Visser, M. E., AND L. J. M. Holleman. 2001. Warmer springs disrupt the synchrony of oak and winter moth phenology. Proceedings of the Roval Societv of London Series B: Biological Sciences 268:289-294.

Walther, G. R., E. Post, P. Convey, A. Menzel, C. Parmesan, T. J. C. Beebee, J. M. Fromentin, O. Hoegh-GuldberG, and F. BAIRLEIN. 2002. Ecological responses to recent climate change. Nature 416:389-395.

WAtters, G. T. 2007. A brief look at freshwater mussel (Unionacea) biology. Pages 51-64 in J. L. Farris and J. H. Van Hassel (editors). Freshwater bivalve ecotoxicology. CRC Press, Boca Raton, Florida, and SETAC Press, Pensacola, Florida.

Weaver, L. R., G. B. Pardue, and R. J. Neves. 1991. Reproductive biology and fish hosts of the Tennessee clubshell Pleurobema oviforme (Mollusca: Unionidae) in Virginia. American Midland Naturalist 126:82-89.
Wellborn, G. A., And J. V. Robinson. 1996. Effects of a thermal effluent on macroinvertebrates in a central Texas reservoir. American Midland Naturalist 136: 110-120.

Williams, J. D., M. L. Warren, K. S. Cummings, J. L. Harris, AND R. J. Neves. 1993. Conservation status of freshwater mussels of the United States and Canada. Fisheries 18(9):6-22.

Wright, S. A., F. M. Holly, A. A. Bradley, And W. Krajewski. 1999. Long-term simulation of thermal regime of Missouri River. Iournal of Hydraulic Engineering 125: 242-252.

ZimMERMAN, L. L., AND R. J. Neves. 2002. Effects of temperature on duration of viability for glochidia of freshwater mussels (Bivalvia: Unionidae). American Malacological Bulletin 17:31-35.

Received: 21 September 2009 Accepted: 21 April 2010 